by Squadron Leader Gayford and Flight-Lieut. Nicholetts in a Fairey monoplane, with a Napier engine, in February 1933. This flight finished at Walvis Bay, only just short of Cape Town, taking 2 days 9 hours 25 minutes. This machine was specially built and equipped for experimental long-distance non-stop flights, and was not entirely a practicable proposition for average everyday flying.

\section{Science in a Changing World}

THe Friday evening discourse at the Royal Institution on May 22 was delivered by Sir Richard Gregory, editor of this journal, who took as his subject "Science in a Changing World". Every week the correspondence columns of NATURE include announcements of new experiments and observations carried out by the authors in various parts of the world. Since its foundation by Sir Norman Lockyer in 1869 , this journal has been the recognised medium for recording such advances in natural knowledge and for the discussion of scientific questions raised by them. Each volume of the hundred and thirty-six which have been published contains noteworthy communications of this kind, and a few of them were mentioned in the discourse. A new era in the history of physical science began just forty years ago. Within a few months, the discoveries were announced of argon, helium, X-rays and radioactivity. It was in the columns of NATURE that Lord Rayleigh first directed attention to the differences of density between nitrogen obtained from the air and from chemical sources which led to the announcement in 1895 of the discovery of argon. Sir William Ramsay also announced there his extraction of helium from the mineral cleveito-twenty-seven years after it had been found by Sir Norman Lockyer in the sun.

THE first translation into English of Röntgen's paper "On a New Kind of Rays" was published in this journal, and also the first suggestion that cathode rays offered the most promising means of producing distant optical vision-now called television. It was in 1908 that Mr. A. A. Campbell Swinton described how cathode ray tubes might be used for this purpose; and his device has now been successfully developed for the transmission and reception of television programmes, such as will shortly be available from Alexandra Palace. Many scientific discoveries, however, have not added to the amenities of life but to its degradation. Sir Richard Gregory urged, therefore, that it has become the duty of men of science to adjust themselves to the conditions of a changing world, and to take an active part in promoting worthy uses of scientific discoveries and preventing the application of new forces to purposes of destruction.

\section{Freud and the Anthropologist}

To mark the occasion of Sigmund Freud's eightieth birthday on May 6, Dr. Géza Róheim, perhaps the most distinguished, and certainly the most experienced exponent of the application of Freud's theories to field investigation in anthropology, evaluates in Man of May his master's contribution to the principles of research among primitive peoples. It is interesting to note that Dr. Róheim, pointing to the fact that the anthropologist's criticism of Freud has been directed mainly against his version of the 'primitive horde' or Cyclopean family, does not himself believe that psycho-analytic anthropology stands or falls with this view of human origins. This is explained in part by Dr. Róheim's general position. Not only does he hold that Freud's minor paperis would explain certain problems to the anthropologist, if the anthropologist would only grasp these explanations ; but also he maintains that the real significance of Freud for the anthropologist does not lie in his contributions to anthropology. The explanation of the apparent paradox is that he stresses Freud's technique as his greatest contribution to the science. In the employment of psycho-analysis he has elaborated a method to explain personality. If, as is now admitted on an overwhelming mass of evidence, this method is valid as applied to Europeans, we must believe a priori that it is applicable at least as a method of investigation to savages, the fundamental psychological unity of mankind being taken for granted. Further, he goes on to point out, as a matter of practice it has been abundantly demonstrated that the dreams of primitive people can be analysed according to the same method and with the same results as the dreams of Europeans. Finally, perhaps the most important point in relation to understanding of the method, Dr. Róheim indicates in response to criticism from the 'functional' school, how and in what sense the term 'neurosis' is not merely individual, but is to be taken as applicable to the group.

\section{U.S. National Academy of Sciences: New Members}

THE following have recently been elected to the U.S. National Academy of Sciences: Prof. Leo H. Baekeland, honorary professor of chemical engineering in Columbia University; Prof. Eliot Blackwelder, professor of geology in Stanford University ; Prof. I. S. Bowen, professor of physics in the California Institute of Technology; Dr. Wallace $H$. Carothers, research chemist in E. I. du Pont de Nemours and Co.; Prof. Alexander Forbes, associate professor of physiology in Harvard University; Prof. W. F. Giauque, associate professor of physical chemistry in the University of California; Prof. Clark L. Hull, professor of psychology in Yale University ; Prof. Edwin O. Jordan, chairman of the Department of Bacteriology at the University of Chicago ; Dr. A. V. Kidder, chairman of the Division of Historical Research of the Carnegie Institution; Prof. Warren H. Lewis, research associate of the Carnegie Institution and professor of physiological anatomy in Johns Hopkins University; Prof. Robert S. Mulliken, professor of physies in the University of Chicago; Prof. Wr. C. Rose, professor of physiological chemistry in the University of Illinois; Prof. Edmund W. Sinnott, professor of botany in Columbia University; Prof. J. L. Walsh, associate professor of mathematics in Harvard University; Dr. Orville Wright, known for his pioneer work on the aeroplane. 